\title{
Assessing the System Vibration of Circular Sawing Machine in Carbonate Rock Sawing Process Using Experimental Study and Machine Learning
}

\author{
Reza Mikaeil • Mojtaba Mokhtarian • Sina Shaffiee Haghshenas • \\ Nicola Careddu (1D) Aref Alipour
}

Received: 10 December 2020/ Accepted: 7 June 2021/Published online: 13 June 2021

(C) The Author(s) 2021

\begin{abstract}
Predicting the vibration of the circular sawing machine is very important in examining the performance of the sawing process, as it shows the amount of energy consumption of the circular sawing machine. Also, this factor is directly related to maintenance cost, such that with a small increase in the level of vibration, the maintenance cost increases to a large extent. This paper presents new prediction models to assess the vibration of circular sawing machine. An evaluation model based on the imperialist competitive algorithm as one of the most efficient artificial intelligence techniques was used for estimation of sawability of the dimension stone in carbonate rocks. For this purpose, four main physical and mechanical properties of rock including Schimazek's F-abrasivity, uniaxial compressive strength, mean Mohs hardness, and Young's modulus as well as two operational parameters of circular sawing machine including depth of cut and feed rate, were investigated and measured. In the predicted model, the system vibration in stone sawing was considered as a dependent variable. The results showed that the system
\end{abstract}

R. Mikaeil · M. Mokhtarian · A. Alipour

University of Technology, Urmia, Iran

S. Shaffiee Haghshenas

University of Calabria, Rende, Italy

N. Careddu $(\bowtie)$

Università degli Studi di Cagliari, Cagliari, Italy

e-mail: ncareddu@unica.it vibration can be investigated using the newly developed machine learning models. It is very suitable to assess the system vibration based on the mechanical properties of rock and operational properties.

Keywords Dimension stone - Carbonate rocks . Sawing process $\cdot$ Vibration $\cdot$ ICA

\section{Introduction}

In dimension stone industry, a range of igneous, metamorphic, and sedimentary rocks are used. These types of dimension stones are commonly known as granite, limestone, marble, travertine, sandstone, and quartzite. The market value of these materials is far higher than that of most minerals currently extracted and varies considerably. Thus, special attention has been given to this issue in the world. One of the most important parts in stone processing is sawing process of extraction blocks. Sawing machines in the building stone processing industry can be divided into circular diamond saw, gang saw and diamond wire saw. Among these devices, circular diamond saw is the most used.

Iran is a mineral-rich country with a high potential in dimension stone. Studies show that Iran is ranked among the 15 major mineral-rich countries (Reichl et al. 2013; Adibi and Ataee-pour 2015). Over the last 
Table 1 Literature review of sawability studies

\begin{tabular}{|c|c|c|c|c|c|c|c|c|c|c|c|c|c|c|}
\hline \multirow[t]{2}{*}{ References } & \multicolumn{2}{|c|}{ Saw type } & \multicolumn{12}{|c|}{ Physical and mechanical properties } \\
\hline & $\mathrm{W}$ & $\mathrm{C}$ & UCS & BTS & YM & IS & SS & $\mathrm{BS}$ & $\mathrm{H}$ & A & $\mathrm{D}$ & Gs & Qc & Ws \\
\hline Burgess (1978) & & 0 & & & & & & & & & & ○ & ○ & \\
\hline Wright and Cassapi (1985) & & 0 & $\bullet$ & 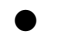 & & & & & 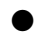 & 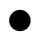 & & & 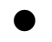 & \\
\hline Birle and Ratterman (1986) & & 0 & & & & & & & ○ & & & & & \\
\hline Jennings and Wright (1989) & & ○ & ○ & ○ & & & & & ○ & & & & ○ & \\
\hline Clausen et al. (1996) & & 0 & & & & & & & & & & ○ & 0 & \\
\hline Ciccu et al. (1998) & O & & & & ○ & & & & O & & & & & O \\
\hline Agus et al. (2003) & O & & & & & & & & O & & & ○ & ○ & \\
\hline Wei et al. (2003) & & ○ & ○ & & & & & & O & ○ & & & ○ & \\
\hline Eyuboglu et al. (2003) & & 0 & $\bullet$ & 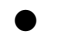 & $\bullet$ & & & & $\mathbf{0}$ & & & & & \\
\hline Ersoy and Atıc1 (2004) & & 0 & ○ & 0 & $\bullet$ & $\bullet$ & ○ & ○ & $\mathbf{0}$ & ○ & ○ & ○ & ○ & \\
\hline Kahraman et al. (2004) & & 0 & ○ & 0 & & - & & & O & ○ & & & & \\
\hline Gunaydin et al. (2004) & & 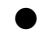 & ○ & ○ & & $\bullet$ & & & & & & & & \\
\hline Ozcelik et al. (2004) & O & & ○ & 0 & ○ & & & & O & & ○ & & ○ & \\
\hline Buyuksagis and Goktan (2005) & & 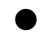 & $\bullet$ & 0 & & & & & 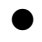 & 0 & & & 0 & \\
\hline Ersoy et al. (2005) & & 0 & ○ & ○ & 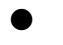 & $\bullet$ & ○ & ○ & & ○ & ○ & & ○ & \\
\hline Delgado et al. (2005) & & 0 & & & & & & & 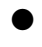 & & & & ○ & \\
\hline Kahraman et al. (2005) & & 0 & & & & & - & & & & & & ○ & \\
\hline Cai et al. (2007) & ○ & & ○ & & ○ & - & & ○ & & & O & & & \\
\hline Fener et al. (2007) & & C & - & 0 & & ? & & & . & ○ & & & & \\
\hline Kahraman et al. (2007) & & 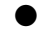 & ○ & 0 & & & & & & & O & & 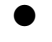 & \\
\hline Özçelik (2007) & 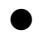 & & $\bullet$ & 0 & & & & & 0 & & & & 0 & \\
\hline Tutmez et al. (2007) & & 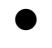 & - & 0 & & - & & & $\bullet$ & $\bullet$ & & & & \\
\hline Buyuksagis (2007) & & 0 & $\bullet$ & 0 & & & & - & & - & - & & $\bullet$ & \\
\hline Mikaeil et al. (2008) & O & & ○ & & & & & & & & & & ○ & \\
\hline Kahraman and Gunaydin (2008) & & 0 & & & & & & & O & & ○ & & & \\
\hline Ataei et al. (2011) & & 0 & ○ & 0 & & & & & ○ & ○ & & & & \\
\hline Mikaeil et al. (2011) & & & ○ & 0 & & & & & & & & & & \\
\hline Ataei et al. (2012) & 0 & & 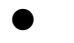 & 0 & & & & & O & 0 & & ○ & 0 & \\
\hline Yurdakul and Akdas (2012) & & & ○ & 0 & & & & ○ & & ○ & O & & & \\
\hline Ghaysari et al. (2012) & ○ & & & & & & & & & & & - & & \\
\hline Mikaeil et al. (2013) & & O & - & 0 & $\bullet$ & & & & O & $\bullet$ & & - & ○ & \\
\hline Sadegheslam et al. (2013) & ○ & & ○ & & ○ & & & & & ○ & & & ○ & \\
\hline Careddu and Cai (2014) & O & ○ & & & & & & & & & & & & \\
\hline Careddu and Lanceni (2015) & ? & ○ & & & & & & & & & & & & \\
\hline Tumac (2015) & & - & & & & & & & 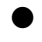 & ○ & & & & \\
\hline Mikaeil et al. (2015) & & 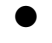 & - & 0 & ○ & & & & O & ○ & & ○ & 0 & \\
\hline Aryafar and Mikaeil (2016) & & & ○ & 0 & ○ & & & & & ○ & & ○ & ○ & \\
\hline Tumac (2016) & & & - & 0 & & & & & & ○ & - & & & \\
\hline Almasi et al. (2017a) & ○ & & ○ & 0 & ○ & & & & & ○ & & ○ & 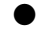 & \\
\hline Almasi et al. (2017b) & 0 & & ○ & 0 & ○ & & & & & ○ & & ○ & ○ & \\
\hline Almasi et al. (2017c) & ○ & & $\bullet$ & 0 & 0 & & & & & - & & $\bullet$ & 0 & \\
\hline Kamran et al. (2017) & 0 & & ○ & & ○ & & & & & ○ & & ○ & ○ & \\
\hline Akhyani et al. (2017) & & & & 0 & 0 & & & & & ○ & & ○ & 0 & \\
\hline
\end{tabular}


Table 1 continued

\begin{tabular}{|c|c|c|c|c|c|c|c|c|c|c|c|c|c|c|}
\hline \multirow[t]{2}{*}{ References } & \multicolumn{2}{|c|}{ Saw type } & \multicolumn{12}{|c|}{ Physical and mechanical properties } \\
\hline & W & $\mathrm{C}$ & UCS & BTS & YM & IS & SS & BS & $\mathrm{H}$ & A & $\mathrm{D}$ & Gs & Qc & Ws \\
\hline Mikaeil et al. (2017) & ○ & & ○ & ○ & - & & & & $\bullet$ & ○ & & - & ○ & \\
\hline Yilmazkaya et al. (2018) & 0 & & 0 & & 0 & 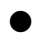 & 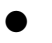 & 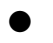 & & 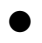 & & $\bullet$ & 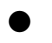 & \\
\hline Tumac and Shaterpour-Mamaghani 2018) & & $\bullet$ & & & 0 & 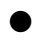 & 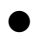 & & & & & $\bullet$ & 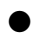 & \\
\hline Aryafar et al. (2018a) & & - & 0 & 0 & 0 & & & & 0 & 0 & & 0 & ○ & \\
\hline Aryafar et al. (2018b) & & $\bullet$ & $\bullet$ & 0 & 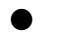 & & & & 0 & 0 & & $\bullet$ & 0 & \\
\hline Akhyani et al. (2018) & & 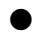 & $\boldsymbol{0}$ & 0 & & & & & & & & & & \\
\hline Mikaeil et al. (2018a) & & $\bullet$ & 0 & 0 & 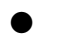 & & & & 0 & ○ & & - & ○ & \\
\hline Mikaeil et al. (2018b) & & 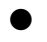 & $\bullet$ & 0 & $\bullet$ & & & & 0 & ○ & & $\bullet$ & 0 & \\
\hline Careddu et al. (2018) & 0 & & 0 & & & & & 0 & & 0 & 0 & & & \\
\hline Careddu et al. (2019) & 0 & & $\bullet$ & & & & & ○ & & 0 & 0 & & & \\
\hline Akhyani et al. (2019) & & & ○ & ○ & 0 & & & & 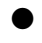 & ○ & & • & ○ & \\
\hline Mohammadi et al. (2019) & & 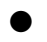 & 0 & $\bullet$ & $\bullet$ & & & & 0 & 0 & & $\bullet$ & 0 & \\
\hline Dormishi et al. (2019a) & & 0 & ○ & 0 & 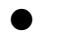 & & & & 0 & 0 & & • & 0 & \\
\hline Dormishi et al. (2019b) & & 0 & $\bullet$ & $\bullet$ & $\bullet$ & & & & O & $\bullet$ & & $\bullet$ & $\bullet$ & \\
\hline Mikaeil et al. (2019a) & & 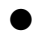 & ○ & - & 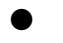 & & & & 0 & 0 & & • & ○ & \\
\hline Haghshenas et al. (2019) & & 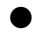 & - & ○ & ○ & & & & O & ○ & & - & ○ & \\
\hline Hosseini et al. (2019) & & & $\bullet$ & ○ & 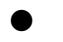 & & & & & 0 & & $\bullet$ & 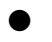 & \\
\hline Hosseini et al. (2020a) & & 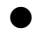 & - & ○ & ○ & & & & ○ & ○ & & - & ○ & \\
\hline Hosseini et al. (2020b) & & 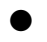 & 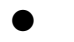 & ○ & 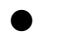 & & & & 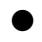 & 0 & & $\bullet$ & 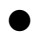 & \\
\hline
\end{tabular}

W, Diamond wire saw; C, Circular saw, Frame saw and Chain saw; UCS, Uniaxial compressive strength; YM, Young's modulus; BTS, Indirect Brazilian tensile strength; IS, Impact strength; SS, Shear strength; BS, Bending strength; H, Hardness; A, Abrasivity; D, Density; Gs, Grain size; Qc, Quartz content; Ws, Wave speed

four decades, many studies in the field of dimensional stone have been done in the world (Table 1). By reviewing the previous studies in Table 1 , it can be seen that the five parameters including uniaxial compressive strength (UCS), indirect Brazilian tensile strength (BTS), hardness (H), abrasivity (A), and quartz content (Qc) have been used widely for modeling and evaluation of sawing process. It was concluded that these parameters are significant in the rock sawing process with diamond wire saw and circular diamond saw.

One of the effective factors in sawing costs is maintenance cost. Along with other cost factors such as labor, energy, water, this factor is very important. This factor can be considered directly related to the vibration of the sawing machine. As a result, predicting machine vibration can play an important role in predicting the cutting costs. In addition, in the sawing process, system vibration is a significant factor of cutting performance in terms of maintenance cost. The rock sawing process inevitably leads to the production of vibrations that are transmitted both on the stone to be sawed and on the tool and the machine. These machines that, when sawing the stone, produce a large amount of vibrations (such as gang saw) require special and expensive reinforced concrete foundations; multi-wire machines certainly have the advantage of producing a lower amount of vibrations thanks to the lower rigidity of the system (Careddu and Cai 2014). However, it is undeniable that the vibrations produced during rock sawing can lead to various problems in the rock (poor flatness of the cut, and/or excessive surface roughness), in the tool (irregular wear, breakage) and in the machine (breakage). The problem of vibration has been studied by many researchers in rock sawing by diamond wire, some kind of "irregular" wear of diamond beads could be explained just by vibration phenomenon of the wire (Cai and Careddu 2013). Dunda and Kujundžić (2001) observed that high velocities of diamond wires 


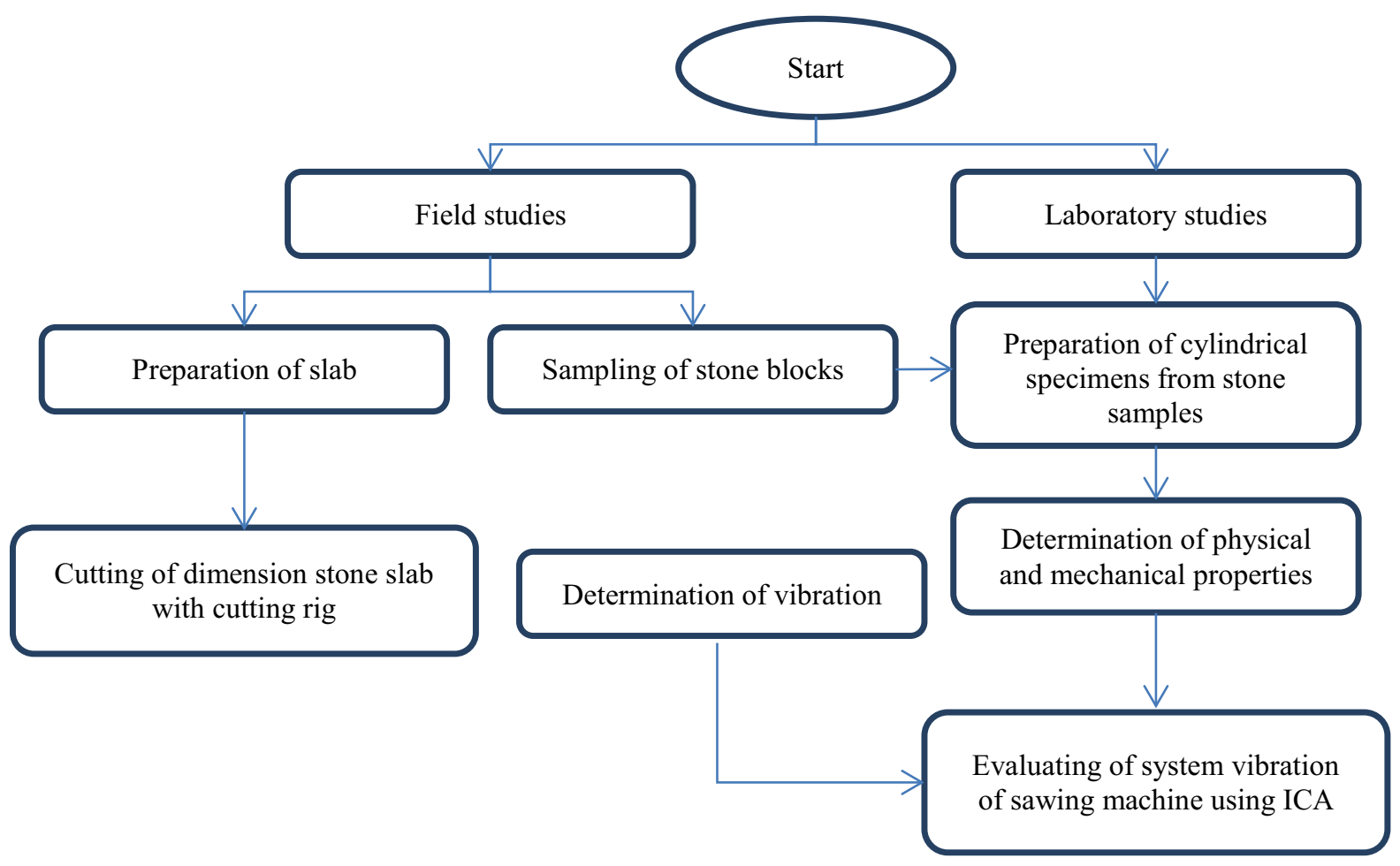

Fig. 1 Flowchart of study

produce vibrations of the rope, caused by dynamic forces, which lead to fatigue-breakage. Polini and Turchetta (2007) monitored tool wear using force and acceleration sensors and found that axial force and vibration affected the amount of tool wear. Tumac (2016) stated that operational parameters of the circular sawing process, such as peripheral speed, saw blade type and diameter have a significant effect on vibration. Geology and rock nature can also affect the development of vibrations in the chain saw cutting process the discontinuities and cracks within the rock mass limit the chain speed since larger chain speed increases vibrations on chain saw arm causing the breakage of the tools (Dagrain et al. 2012).

The major factors that need consideration in evaluating the system vibration, particularly for stone cutting, are the properties of the rock and the operational parameters of the saw as well as the type of equipment (gang-saw, multi-wire, and block-cutter). In this study, new models were developed to evaluate the system vibration in the stone sawing process by means of a circular diamond saw. Using these developed models, more economic analysis as a decisionmaking index can be done for project planning.
This study is organized as follows. After introduction in the first section, the methodology of the study is presented. In the third section, the studied quarries and laboratory study are explained. In the fourth section, the new models are developed to predict the system vibration using the imperialist competitive algorithm. Finally, the fifth section reviews the results of the models. This section concludes and discusses the paper.

\section{Methodology}

This study is generally organized into two main sections. Field and laboratory studies were performed to create statistical data in the first section. Finally, soft computing was carried out to evaluate the cutting performance of circular sawing machine. Figure 1 displays the flowchart of this study.

\subsection{Imperialist Competitive Algorithm}

Artificial intelligence techniques are one of the most popular ways to solve complex problems in industry and economics sectors (Mahdevari et al. 2017; 


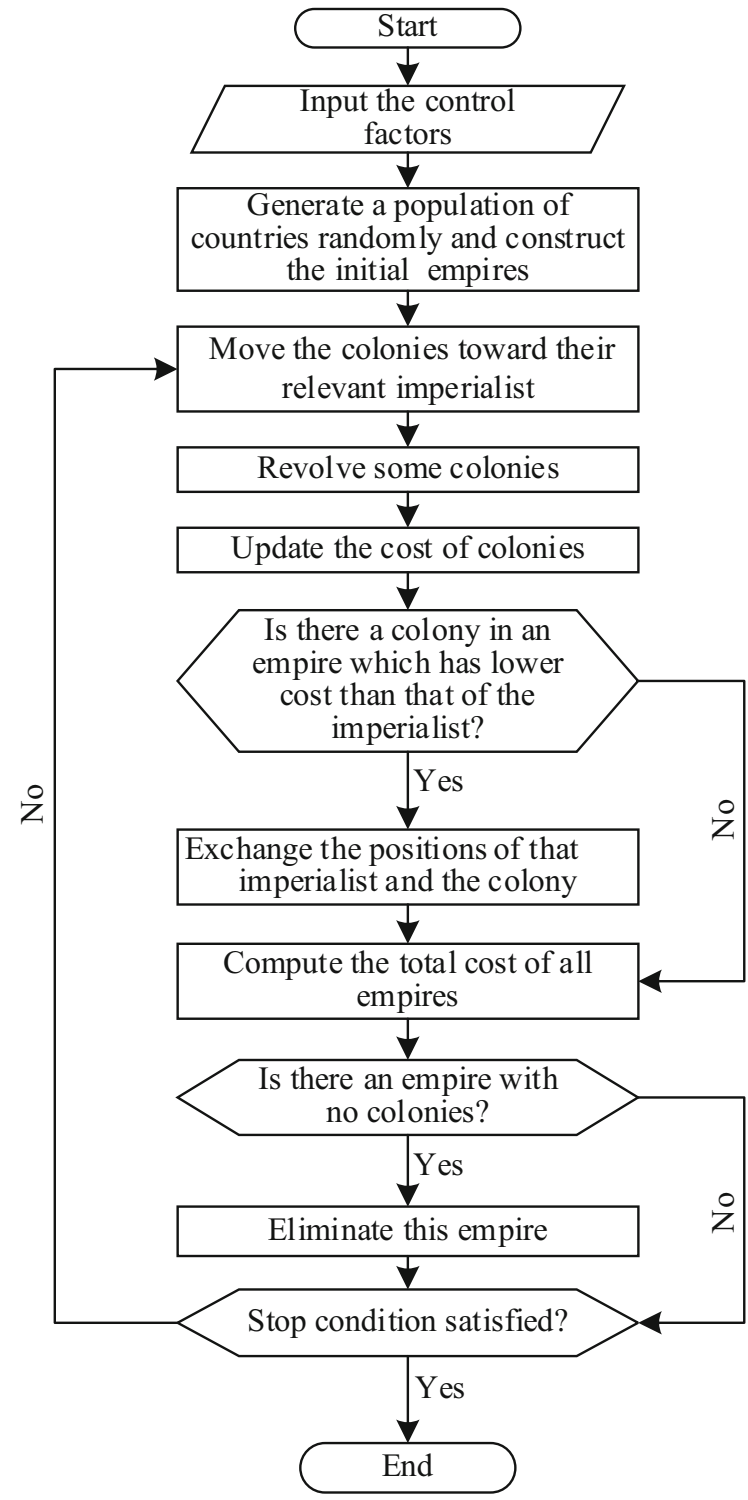

Fig. 2 Flowchart of imperialist competitive algorithm

Naderpour et al. 2019; Zhang and Geem 2019; Kayabekir et al. 2020; Daneshvar and Behnood 2020; Guido et al. 2020a; Kandiri et al. 2020). In recent years, several studies have been conducted on the application of artificial intelligence in engineering problems (Geem and Kim 2018; Mikaeil et al. 2018c, 2019b, c, d; Salemi et al. 2018; Gnawali et al. 2019; Park et al. 2020; Shaffiee Haghshenas et al. 2020; Noori et al. 2020; Fiorini Morosini et al. 2020; Guido et al. 2020b). One of the most efficient methods of artificial intelligence is the imperialist competitive algorithm (ICA), suggested by Atashpaz-Gargari and Lucas (Khabbazi et al. 2009;
Haghshenas et al. 2017). The capability of algorithm to solve the different types of optimization problems has been studied by the authors in Atashpaz-Gargari and Lucas 2007; Nazari-Shirkouhi et al. 2010; Shokrollahpour et al. 2011; Maroufmashat et al. 2014; Ardalan et al. 2015; Sadaei et al. 2016; Sharifi and Mojallali 2016; Mokhtarian Asl and Sattarvand et al. 2016. As other evolutionary algorithms, the ICA begins with an initial number of solutions that are called countries. Each solution represents the concept of the nations and reflects the quality of objective function in each solution. The best solutions or countries are elected as 'imperialists' while the remaining solutions are categorized as the 'colonies' of those imperialists. An imperialist and the colonies form an 'empire' (Shokrollahpour et al. 2011). Gradually, imperialists seek to extend their characteristics to the colonies under their control. Still, the procedure is not fully controlled and revolutions are expected. Countries may also leave one empire to join another provided that the new one gives them more chance of promotion. Figure 2 displays the flowchart of the ICA. In the following, the methodology for implementation of ICA will be explained step by step.

Step 1 Generating initial empires: The optimization algorithm starts with an initial population that is created consisting of $N_{\text {pop }}$ solutions including $N_{i m p}$ of the strongest that represent the imperialists. The remaining members of the population $\left(N_{c o l}=N_{\text {pop }}-N_{\text {imp }}\right)$ represent the colonies of the empires. The primary empires and colonies are separated among the imperialists given their power as the higher the power of an empire, the more the colonies covered by it. To distribute the colonies among imperialists based on their power, the normalized cost of $n^{\text {th }}$ imperialist is given as follows (Atashpaz-Gargari and Lucas 2007):

$C_{n}=\max \left\{c_{i}\right\}-c_{n}, \quad i=1,2, \ldots, N_{i m p}$

where $c_{n}$ and $C_{n}$ represent the cost and the normalized cost of $n$th imperialist respectively. Thus, each imperialist's normalized power is determined as follows (Atashpaz-Gargari and Lucas 2007):

pow $_{n}=\left|\frac{C_{n}}{\sum_{i=1}^{N_{i m p}} C_{i}}\right|$ 
The number of colonies that can be controlled by an imperialist is determined by its normalized power. Hence, the count of colonies of an empire at beginning is given as (Atashpaz-Gargari and Lucas 2007; Haghshenas et al. 2017):

$$
\operatorname{ColEmp}_{n}=\operatorname{round}\left(\text { pow }_{n} \times N_{\text {col }}\right)
$$

where ColEmp ${ }_{n}$ is the starting number of the colonies of $n$th empire that are determined in the whole colony population randomly.

Step 2 Assimilation process: The colony can move towards the imperialist on different socio-political axes such as culture and language. The colony can approach the imperialist by $x$ units, while $x$ stands for a random number with uniform distribution.

Step 3 Revolution: The operator diversifies ICA to examine new regions. The mechanism protects the algorithm from being trapped in local optima. Thus, each iteration selects the weakest colony and randomly replaces it with a new one.

Step 4 Imperialist and a colony substitution: It is possible for a colony to reach the position where cost function is less than that of its imperialist. When this happens, the colony and imperialist replace their position.

Step 5 Calculating the total power of an empire: It is obtained based on the power of its imperialist country, while the powers of its individual colonies have also important influence, which is relatively insignificant. Thus, the total cost of an empire is as:

$$
\begin{aligned}
& T C=\operatorname{cost}\left(\text { imperialist }_{n}\right) \\
& +\xi \text { mean }\left(\cos t\left(\text { colonies of empire }_{n}\right)\right)
\end{aligned}
$$

where $T C$ represents the total cost of the $n^{\text {th }}$ empire and $\xi$ stands for positive number which is considered less than 1 .

Step 6 Imperialistic competition: The competition is modeled by choosing one of the weakest colonies that belongs to the weakest empire and making a competition among all empires to possess this colony. The possession probability of each empire is proportional to its total power. The normalized total cost of each empire is determined as follows (Eq. (5)):

$N T C_{n}=\max \left\{T C_{i}\right\}-T C_{n} \quad i=1,2, \ldots, N_{i m p}$

where $T C_{n}$ and $N T C_{n}$ represent the total cost and normalized total cost of $n$th empire respectively. Now the chance of possession for each empire is given by:

$p_{n}=\left|\frac{N T C_{n}}{\sum_{i=1}^{N_{i m p}} N T C_{i}}\right|$

To determine the share of each empire of the noted colonies, vector $P$ is formed as follows:

$P=\left[p_{1}, p_{2}, p_{3}, \ldots, p_{N_{\text {imp }}}\right]$

Afterwards, the vector $R$ equal to $\mathrm{P}$ in size is created of which the elements are uniformly distributed random numbers between 0 and 1 .

$r=\left[r_{1}, r_{2}, r_{3}, \ldots, r_{i m p}\right], \quad r_{1}, r_{2}, r_{3}, \ldots, r_{i m p} \sim U(0,1)$

Then, vector $D$ is formed by subtracting $R$ from $P$.

$$
\begin{aligned}
D & =P-R=\left[d_{1}, d_{2}, d_{3}, \ldots, d_{N_{i m p}}\right] \\
& =\left[p_{1}-r_{1}, p_{2}-r_{2}, p_{3}-r_{3}, \ldots, p_{N_{i m p}}-r_{N_{i m p}}\right]
\end{aligned}
$$

Based on vector $D$, the colonies will be subjected to an empire whose corresponding index of empire in D is maximum. (Atashpaz-Gargari and Lucas 2007; Haghshenas et al. 2017).

Step 7 Removing the empires without power: Empires without power will not survive in the imperialistic competition and the colonies they have are taken by other empires. Here, an empire falls when all its colonies are lost.

Step 8 Stopping criteria: when no iteration remains or only one empires controls the whole world, the algorithm stops.

\section{Studied Quarries and Laboratory Study}

In this paper, twelve famous Iranian quarries are studied. The names and locations of these quarries are presented in Table 2 and Fig. 3, respectively. 
Table 2 The names of studied quarries

\begin{tabular}{|c|c|c|c|c|}
\hline & Name samples & Rock sample & Type & Quarry \\
\hline $\mathrm{S} 1$ & CHM & Cream Harsin & Marble & Zolfaghar \\
\hline S2 & PAM & Pink Anarak & Marble & Golsang \\
\hline S3 & RT & Red & Travertine & Azarshahr \\
\hline S4 & HT & Hajiabad & Travertine & Hajiabad \\
\hline S5 & DT & Darebokhari & Travertine & Darebokhari \\
\hline S6 & SM & Salsali & Marble & Salsali \\
\hline S7 & PM & Pink & Marble & Haftoman \\
\hline
\end{tabular}

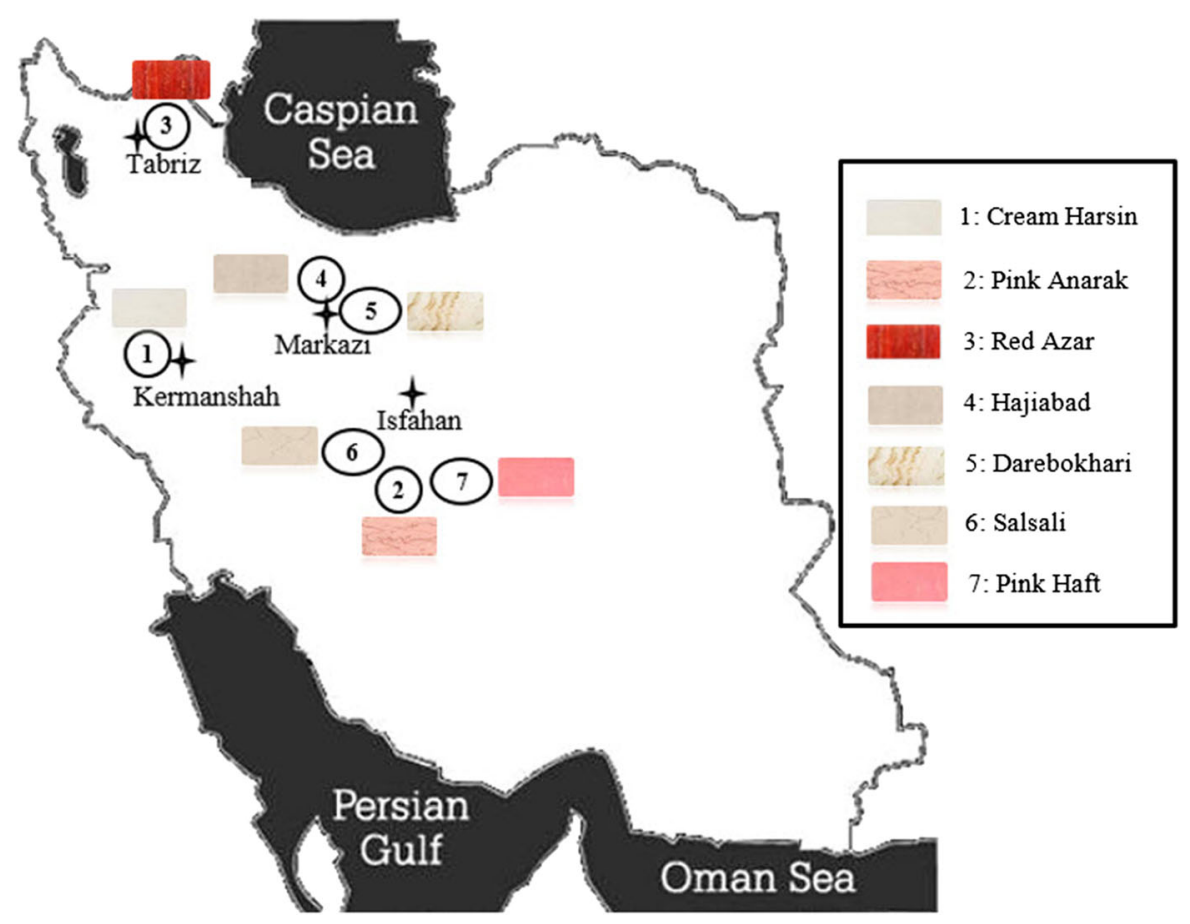

Fig. 3 The location of studied quarries 
Table 3 The results of laboratory studies

\begin{tabular}{llllllll}
\hline Name samples & $\begin{array}{l}\text { UCS } \\
\text { MPa }\end{array}$ & $\begin{array}{l}\text { BTS } \\
\text { MPa }\end{array}$ & $\begin{array}{l}\mathrm{Q}_{\mathrm{C}} \\
\%\end{array}$ & $\begin{array}{l}\text { Gs } \\
\mathrm{mm}\end{array}$ & $\begin{array}{l}\text { SF-a } \\
\text { N/mm }\end{array}$ & $\begin{array}{l}\text { YM } \\
\text { GPa }\end{array}$ & $\begin{array}{l}\text { MH } \\
n\end{array}$ \\
\hline S1 & 71.5 & 6.8 & 3.6 & 0.55 & 0.135 & 32.5 & 3.5 \\
S2 & 74.5 & 7.1 & 3.4 & 0.45 & 0.109 & 33.6 & 3.2 \\
S3 & 53 & 4.3 & 2.8 & 1.01 & 0.122 & 20.7 & 2.9 \\
S4 & 61.5 & 5.6 & 2.6 & 0.85 & 0.124 & 21 & 2.9 \\
S5 & 63 & 5.4 & 2.7 & 0.87 & 0.127 & 23.5 & 2.95 \\
S6 & 68 & 6.3 & 3.2 & 0.52 & 0.105 & 31.6 & 3.1 \\
S7 & 74.5 & 7.2 & 4 & 0.6 & 0.173 & 35.5 & 3.6 \\
\hline
\end{tabular}
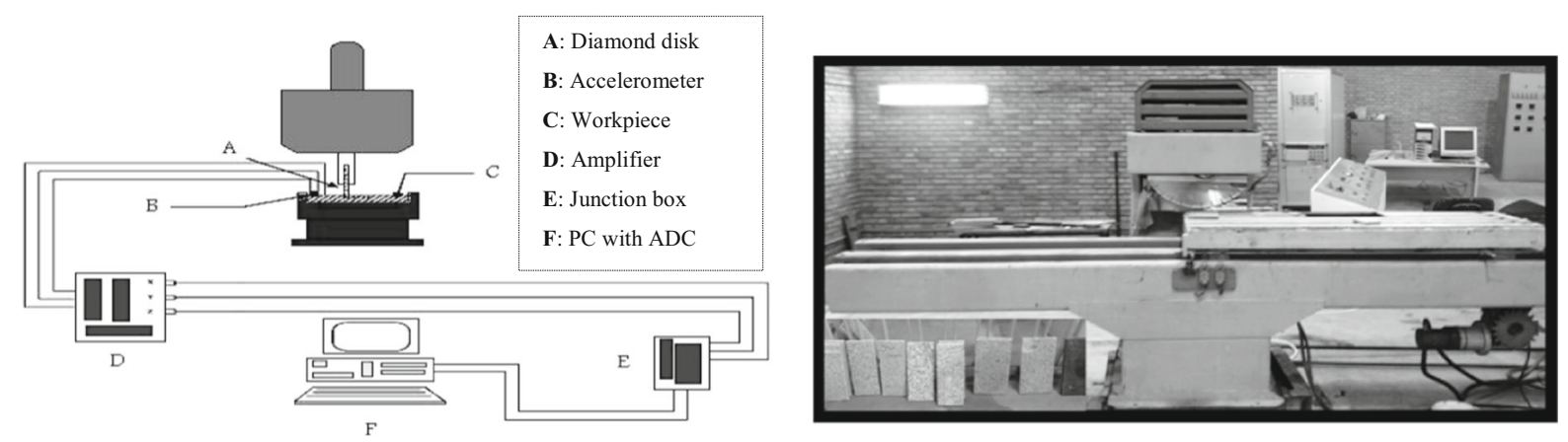

Fig. 4 A schematic diagram of the adopted sensor system and laboratory sawing rig

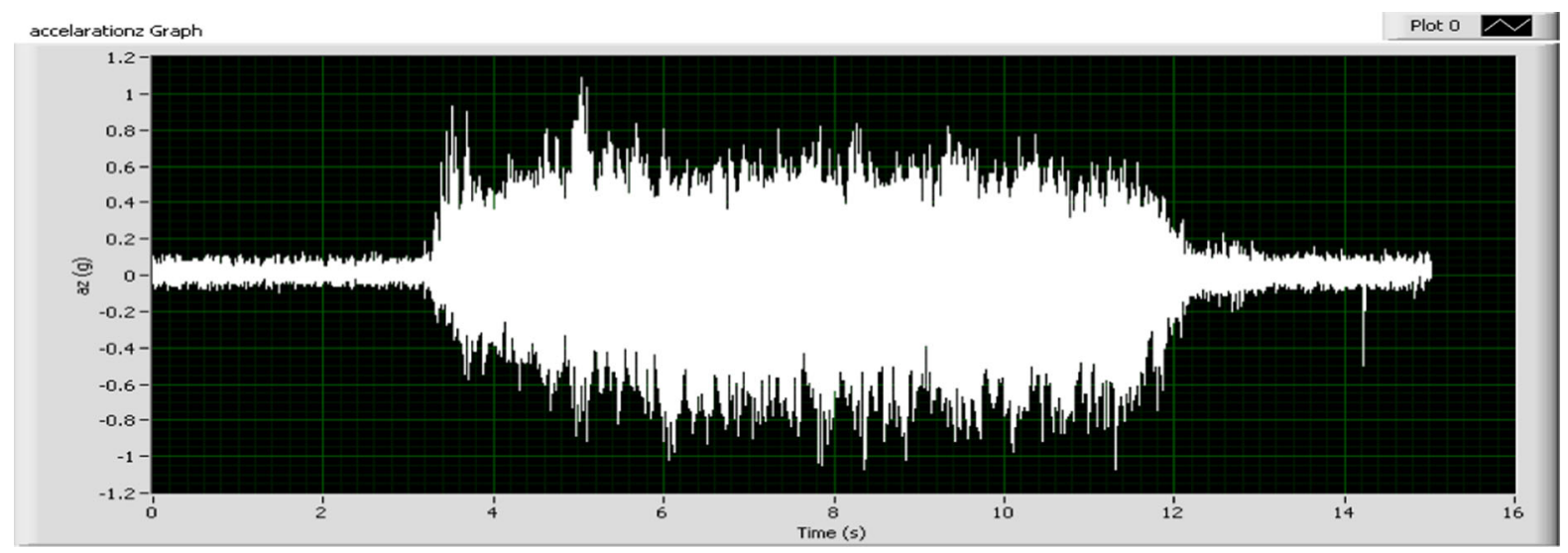

Fig. 5 Typical time-domain acceleration signals monitored at the different time interval

The samples of the studied dimension stones were prepared from quarries. Then, they were transferred to the rock mechanics laboratory to determine four major physical and mechanical parameters including, Schmiazek F-abrasivity factor (SF-a), Mohs Hardness (MH), Uniaxial Compressive Strength (UCS), and Young's Modulus (YM). Finally, standard tests were completed to measure these parameters according to the procedures suggested by the ISRM standards (ISRM 1981).

The UCS test was carried out using a servo controlled testing machine designed for rock test under a loading rate of $1 \mathrm{MPa} / \mathrm{s}$. Finally, the average UCS was considered for each studied dimension stone.

The Schimazek's F-abrasiveness factor is calculated by Eq. 10 (Schimazek and Knatz 1970). 
Table 4 The range of used parameter in this study

\begin{tabular}{lllrrr}
\hline Parameter & Unit & Category & min & mean & max \\
\hline Depth of cut & $\mathrm{cm}$ & input & 1.50 & 2.53 & 3.60 \\
Feed rate & $\mathrm{m} / \mathrm{s}$ & input & 1.00 & 2.50 & 4.00 \\
Mohs hardness & $\mathrm{n}$ & input & 2.90 & 3.18 & 3.60 \\
Young's Modulus & $\mathrm{GPa}$ & input & 20.70 & 28.65 & 35.50 \\
Uniaxial Compressive Strength & $\mathrm{MPa}$ & input & 53.00 & 67.55 & 74.50 \\
Schmiazek F-abrasivity factor & $\mathrm{N} / \mathrm{cm}$ & input & 1.05 & 1.28 & 1.73 \\
RMS & $\mathrm{m} / \mathrm{s}^{2}$ & output & 0.98 & 2.16 & 3.92 \\
\hline
\end{tabular}

For monitoring the vibration in stone cutting, an adopted sensor system was designed (Fig. 4).

An accelerometer (ADXL105-3) was used to measure the acceleration of workpiece in the sawing process. A monitoring strategy was adopted based on time domain characteristics. Figure 5 illustrates monitored time-domain signals.

Then, the signals were analyzed using a feature extraction program in Labview. The Root Mean Square Amplitude feature (RMS) according to Eq. (12) was extracted for the acceleration signals. Equation (12) shows the RMS value of a function $\mathrm{x}(\mathrm{t})$ over an interval of $\mathrm{T}$.

$X_{r m s}=\sqrt{\frac{\int_{0}^{T} x(t)^{2} d t}{T}}$

During the sawing trials, the acceleration signal and RMSaz for each rock were monitored and calculated at different FRs and DCs. The results of experimental studies were taken into account to establish the models. The range of the parameters used in this study is summarized in Table 4.

\section{Prediction of System Vibration by ICA}

The present section describes the model development procedure of ICA in estimating RMSa. In this regard, two models are proposed for predicting the RMSa and then ICA is used for determining their coefficients. The general forms of proposed models are presented in Eqs. (13) and (14): (size $40 \times 10 \times 3 \mathrm{~mm}$ ) were brazed to the periphery of circular steel core with a standard narrow radial slot. The grit sizes of the diamond were approximately $30 / 40$ US mesh at 25 and 30 concentrations. The acceleration signal was acquired along the whole cut. 


$$
\begin{aligned}
R M S_{I}=k_{0} & +k_{1} \times D C_{i}^{k_{2}}+k_{3} \times F R_{i}^{k_{4}}+k_{5} \times M H_{i}^{k_{6}} \\
& +k_{7} \times Y M_{i}^{k_{8}}+k_{9} \times U C S_{i}^{k_{10}}+k_{11} \\
& \times S F-a_{i}^{k_{12}}
\end{aligned}
$$

$$
\begin{aligned}
R M S_{I I}= & k_{0}+k_{1} \times D C_{i}^{k_{2}} \times F R_{i}^{k_{3}} \times M H_{i}^{k_{4}} \times Y M_{i}^{k_{5}} \\
& \times U C S_{i}^{k_{6}} \times S F-a_{i}^{k_{7}}
\end{aligned}
$$

where DC is depth of cut in mm, FR denotes feed rate (cm/min), MH (n), YM (GPa), UCS (MPa), and SF-a $(\mathrm{N} / \mathrm{mm})$. These parameters were set as the independent parameters of the model, while RMSa was considered as the dependent parameter. $\mathrm{k}_{0}, \mathrm{k}_{1}, \mathrm{k}_{2}, \ldots \mathrm{k}_{12}$ are unknown coefficients that must be adjusted to minimize the dependent parameter prediction error. The ICA approach has been used for this purpose. First, 800 random values for coefficients was considered as a first countries. Out of 800 randomly selected countries, 25 countries with the least estimation error were considered as imperialists. Then the primitive countries were according to the imperialists to form empires and colonial competition according to flowchart shown in Fig. 2, was done between empires to set the best values for the coefficients. Indeed, based on the lowest values of fitness function, ICA tries to find the fittest model to the available data. This is possible through minimizing errors between the measured values of RMSa and the estimated ones. Hence, the used fitness function for solving the problem of this study is the Mean Squared Error (MSE) function, which can be defined as follows:

Minimize $\frac{1}{n} \sum_{i=1}^{n}\left(R M S a_{E s t i}-R M S a_{M e a s}\right)^{2}$
$\mathrm{RMSa}_{\text {Meas }}$ and $\mathrm{RMSa}_{\text {Est } i}$ are the measured RMSa data, and the estimated ones by the model, respectively and $n$ denotes the number of data.

The procedure proposed for applying ICA to predicting $\mathrm{RMSa}$ has been implemented in $\mathrm{C}++$ programming language. In order to achieve the optimum ICA parameters, some of the previous studies were studied (Atashpaz-Gargari and Lucas 2007; Ahmadi et al. 2013; Ebrahimi et al. 2014). The best values of $\zeta, \beta, \mathrm{N}_{\mathrm{pop}}$, and $\mathrm{N}_{\mathrm{imp}}$ were considered as $0.05,1.75,800$, and 25 , respectively.

Considering the used ICA parameters in this study, the proposed models for predicting RMSa values resulting from field recorded data sites are shown in Eqs. (16) and (17), respectively.

$$
\begin{aligned}
R M S_{I}=- & 2.207-2.671 \times D C_{i}^{-0.2683}+5.862 \\
& \times F R_{i}^{0.176}-15902.6 \times M H_{i}^{-9.471}-6.7 \\
& \times Y M_{i}^{-7.282}-3.874 \times U C S_{i}^{-10.843} \\
& +6.731 \times S F-a_{i}^{-50.576}
\end{aligned}
$$

$$
\begin{aligned}
R M S_{I I}=- & 0.1376+0.0567 \times D C_{i}^{0.2673} \times F R_{i}^{0.5466} \\
& \times M H_{i}^{-0.5277} \times Y M_{i}^{0.5558} \times U C S_{i}^{0.4134} \times S F-a_{i}^{0.0045}
\end{aligned}
$$

\begin{tabular}{|c|c|c|c|c|c|c|c|c|c|c|}
\hline \multirow[t]{3}{*}{ Predictive model } & \multicolumn{10}{|c|}{ Statistical criteria } \\
\hline & \multicolumn{2}{|l|}{ MAPE } & \multicolumn{2}{|l|}{ RMSE } & \multicolumn{2}{|l|}{ VARE } & \multicolumn{2}{|l|}{ VAF } & \multicolumn{2}{|l|}{$\mathrm{CC}$} \\
\hline & Model & Test & Model & Test & Model & Test & Model & Test & Model & Test \\
\hline $\mathrm{RMS}_{\mathrm{I}}$ & 8.241 & 8.944 & 0.192 & 0.210 & 0.632 & 0.867 & 93.345 & 90.269 & 0.976 & 0.953 \\
\hline $\mathrm{RMS}_{\mathrm{II}}$ & 6.674 & 6.531 & 0.195 & 0.206 & 0.302 & 0.328 & 93.103 & 90.670 & 0.975 & 0.954 \\
\hline
\end{tabular}

\section{Results and Discussion}

System vibration in rock sawing process depends on two groups, including controlled parameters related to operational parameters and tool characteristics and non-controlled parameters related to rock characteristics. Under the same working conditions, the cutting results are strongly affected by rock characteristics such as strength, hardness, and abrasiveness as well as

Table 5 The value of statistical criteria for the predictive models 


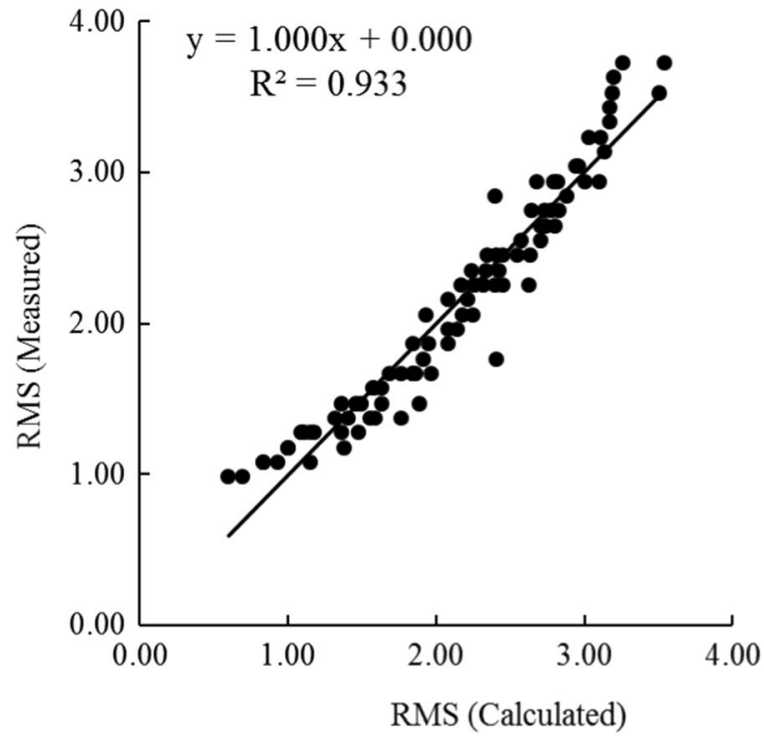

(a) Model

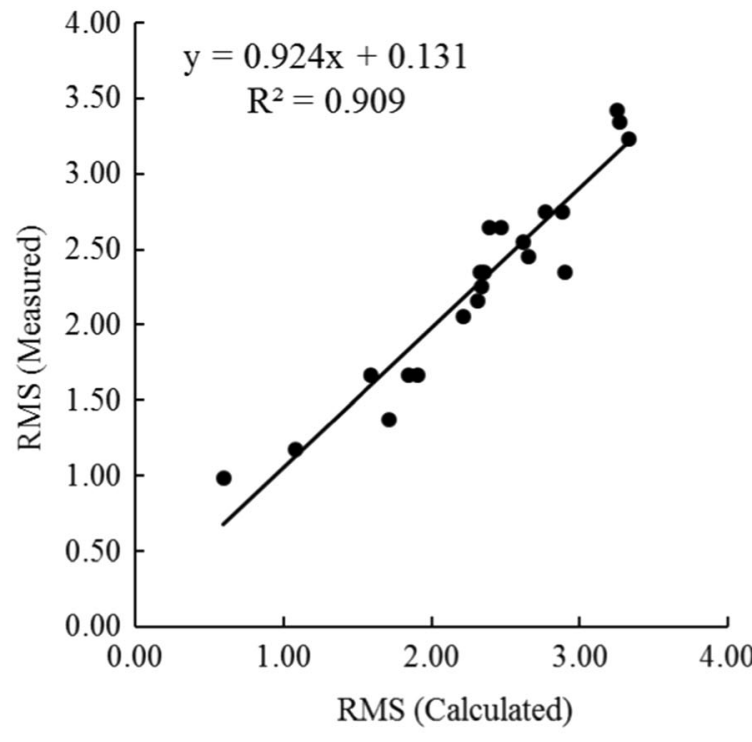

(b) Test

Fig. 6 Measured versus predicted RMS by model RMS $\mathrm{I}_{\mathrm{I}}$ a. model data and $\mathrm{b}$. test data

operational parameters such as feed rate and depth of cut. In the present research, two ICA models were presented for predicting the system vibration in terms of RMSa in 7 famous dimension stones in Iran. To develop the predictive models, $80 \%$ of the total data were randomly selected while the rest of the data $(20 \%$ of whole data) were assigned for testing purposes. Specifically, 90 datasets from the whole 112 datasets were used to construct the predictive models and 22 data were used to test the constructed models. In the developed models, the DC $(\mathrm{cm}), \mathrm{FR}(\mathrm{cm} / \mathrm{min}), \mathrm{MH}$ (n), YM (GPa), UCS (MPa), and SF-a (N/mm) were

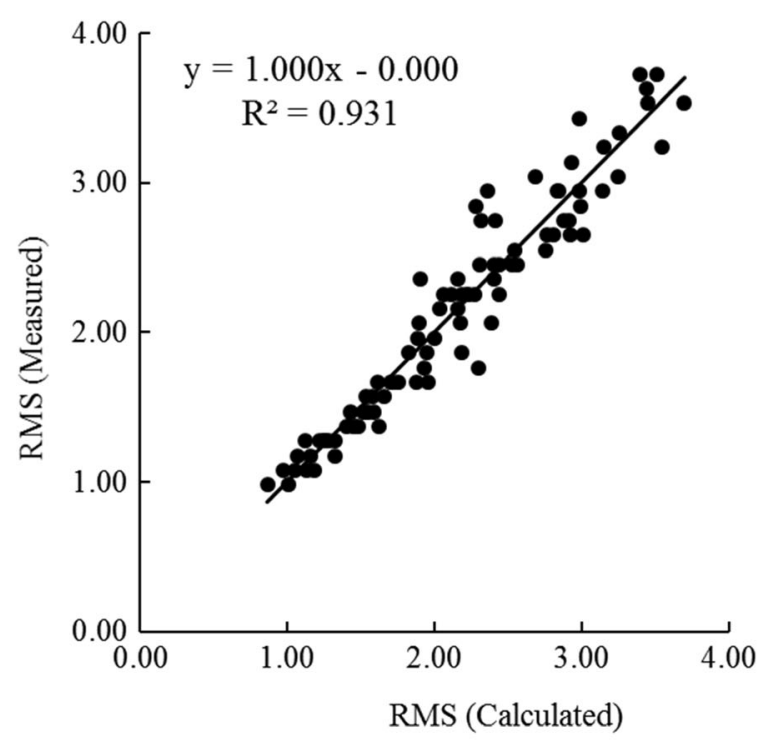

(a) Model

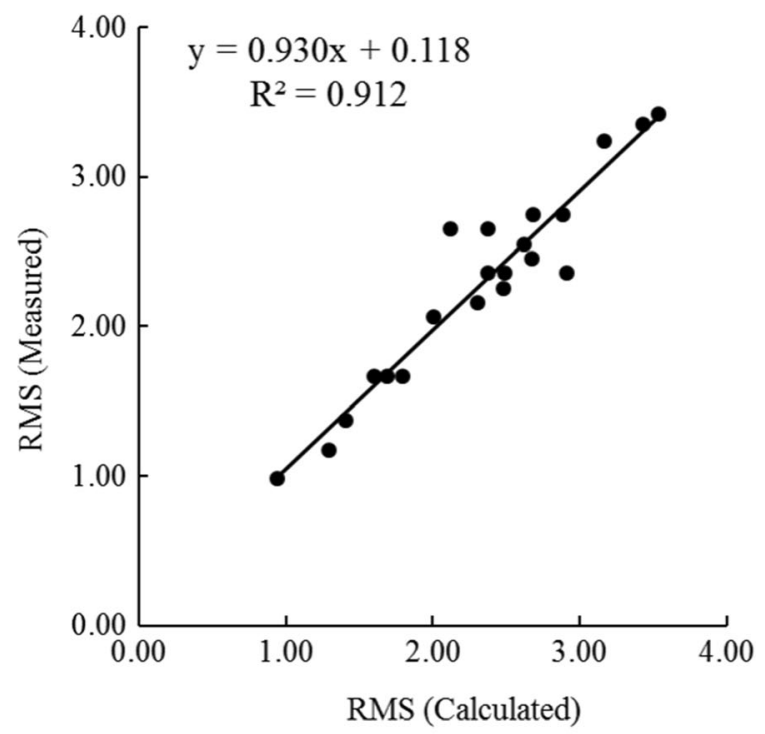

(b) Test

Fig. 7 Measured versus predicted RMS by model $\mathrm{RMS}_{\mathrm{II}}$ a. model data and b. test data 


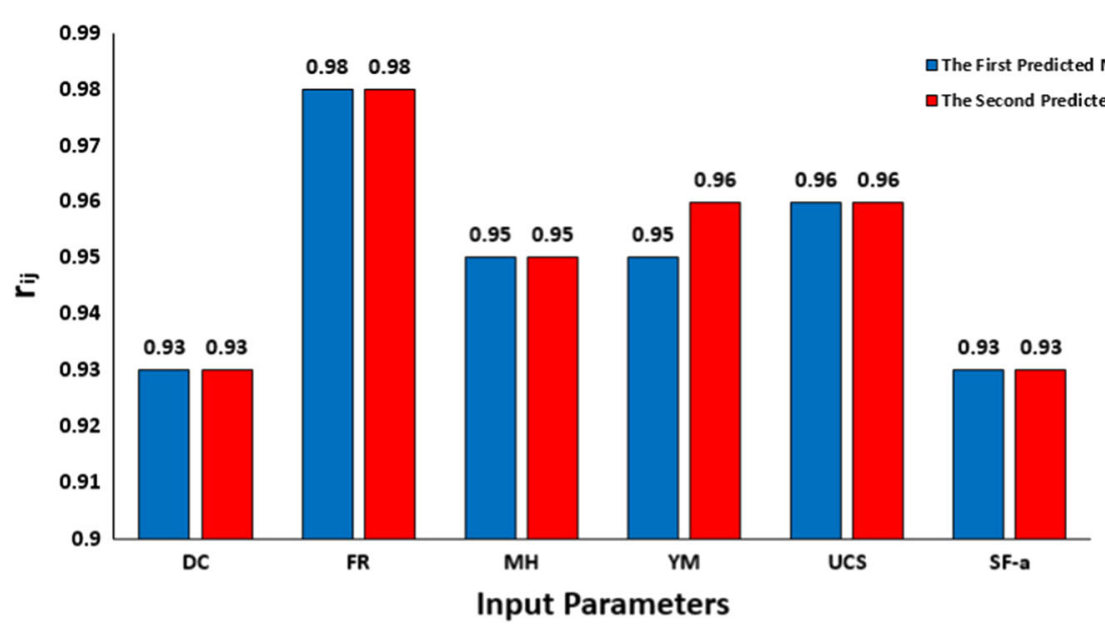

Fig. 8 The strength of the relation between input parameters and the predicted models

set as independent parameters, while RMS $\left(\mathrm{m} / \mathrm{s}^{2}\right)$ was set as the dependent parameter. The performance of the models was controlled using statistical tests, i.e., Mean Absolute Percentage Error (MAPE), Root Mean Square Error (RMSE), Variance Absolute Relative Error (VARE), Variance Account For (VAF), and Correlation Coefficient (CC). These indices can be computed using Eqs. $(18,19)$, respectively.

MAPE $=\frac{1}{n} \times\left[\sum_{i=1}^{i=n}\left|\frac{R M S_{\text {Meas }}^{i}-R M S_{\text {Esti }}^{i}}{R M S_{\text {Meas }}^{i}}\right|\right] \times 100$

$R M S E=\sqrt{\frac{1}{n} \times \sum_{i=1}^{i=n}\left(R M S_{\text {Meas }}^{i}-R M S_{E s t i}^{i}\right)^{2}}$

$V A R E=\operatorname{var}\left(\left|\frac{R M S_{\text {Meas }}-R M S_{\text {Esti }}}{R M S_{\text {Meas }}}\right|\right) \times 100$

$V A F=\left[1-\frac{\operatorname{var}\left(R M S_{\text {Meas }}-R M S_{\text {Esti }}\right)}{\operatorname{var}\left(R M S_{\text {Meas }}\right)}\right] \times 100$

$C C=\frac{\sum_{i=1}^{i=n}\left[\left(R M S_{\text {Meas }}^{i}-\overline{R M S_{\text {Meas }}^{i}}\right)\left(R M S_{\text {Esti }}^{i}-\overline{R M S_{E s t i}^{i}}\right)\right]}{\sqrt{\sum_{i=1}^{i=n}\left(R M S_{\text {Meas }}^{i}-\overline{R O P_{\text {Meas }}^{i}}\right)^{2} \times \sum_{i=1}^{i=n}\left(R M S_{\text {Esti }}^{i}-\overline{R M S_{\text {Esti }}^{i}}\right)^{2}}}$

The results of these statistical criteria for two predictive models and test data are reported in Table 5.
Note that lower values of MAPE, RMSE, and VARE, and higher values VAF and CC indicate the best approximation. As can be seen in Table 5, when considering the obtained results of the MAPE for the $\mathrm{RMS}_{\text {II }}$ model, the value of 6.674 was observed, while this value for the $\mathrm{RMS}_{\mathrm{I}}$ model was 8.241. These values reveal a higher accuracy of the $\mathrm{RMS}_{\mathrm{II}}$. The scatter plot comparing measured and predicted RMS values for the RMS I and RMS II is shown in Figs. 6 and 7. Considering the obtained results of $\mathrm{R}^{2}$ for the $\mathrm{RMS}_{\mathrm{I}}$ and $\mathrm{RMS}_{\text {II }}$ models, the value of 0.93 was observed for the model data, the results revealed the high accuracy of both models. The value of $\mathrm{R}^{2}$ for test data is 0.9 , which has also acceptable accuracy.

Finally, in order to assess the effectiveness of input parameters on the predicted RMS, a sensitivity analysis was also performed using the cosine amplitude method based upon Eq. (23). Where $r_{i j}$ represents the strength of the relation, $\mathrm{n}$ is the number of dataset, and the $\mathrm{x}_{\mathrm{ik}}$ and $\mathrm{y}_{\mathrm{ij}}$ denotes input parameters and the predicted output, respectively (Yang and Zhang 1997).

$r_{i j}=\frac{\sum_{k=1}^{n}\left(x_{i k} \times y_{j k}\right)}{\sqrt{\sum_{k=1}^{n} x_{i k}^{2} \sum_{k=1}^{n} y_{i k}^{2}}}$

The results of sensitivity analysis for two models are shown in Fig. 8. According to the results, the feed rate had a high impact on the predicted RMS with strength of the relation being equal to 0.98 in both models. Then, the Mohs hardness, Young's modulus, and uniaxial compressive strength had almost equal effects on the predicted output in two models. However, the depth of cut and Schimazek's 
F-abrasivity with a correlation of 0.93 , had the lowest effect on the predicted output. Finally, it is worth mentioning that the proposed equations in this study can only be used in studied quarries and circular diamond saw, in the other word, they are unique models.

\section{Conclusion}

The production cost in dimension stone factory is affected by numerous factors such as diamond saw, energy consumption, maintenance, labor, water, and polishing pads, filling material, and packing. Also, the level of system vibration has a great impact on the maintenance cost. Thus, controlling the system vibration level can help reduce the maintenance cost. In the present study, two predicted models based on the imperialist competitive algorithm (ICA) were developed for predicting the system vibration in the dimension stone sawing process in 7 famous quarries in Iran. In the developed models, the depth of cut $(\mathrm{cm})$, feed rate $(\mathrm{m} / \mathrm{s})$, Mohs hardness, Young's modulus (GPa), uniaxial compressive strength (MPa), and Schimazek's F-abrasivity $(\mathrm{N} / \mathrm{cm})$ were set as independent parameters, while Root Mean Square $\left(\mathrm{m} / \mathrm{s}^{2}\right)$ was set as the dependent variable. The performance of the developed predictive models was controlled by statistical functions, i.e., Mean Absolute Percentage Error (MAPE), Root Mean Square Error (RMSE), Variance Absolute Relative Error (VARE), Variance Accounted For (VAF), and Correlation Coefficient (CC). Finally, the results of models showed that ICA was able to assess the vibration of different rocks in the carbonate group with a low acceptable error and the models can be applied for rock vibration estimation in practice. Furthermore, the modeling of vibration in sawing processes can be a reliable system for high benefit and low-cost models for industrial applications and enables factory managers to have an accurate prediction of maintenance and energy costs. For future work, it is recommended to consider other operational parameters that also affect the vibration, such as the blade flatness and tensioning or the water flow and then comparing results with each other.

Acknowledgements It is gratefully noted that the project is supported by Professor Mahdi Ghaem. We are also grateful to anonymous reviewers for their advices and contributions to this paper.

Funding Open access funding provided by Università degli Studi di Cagliari within the CRUI-CARE Agreement.

Open Access This article is licensed under a Creative Commons Attribution 4.0 International License, which permits use, sharing, adaptation, distribution and reproduction in any medium or format, as long as you give appropriate credit to the original author(s) and the source, provide a link to the Creative Commons licence, and indicate if changes were made. The images or other third party material in this article are included in the article's Creative Commons licence, unless indicated otherwise in a credit line to the material. If material is not included in the article's Creative Commons licence and your intended use is not permitted by statutory regulation or exceeds the permitted use, you will need to obtain permission directly from the copyright holder. To view a copy of this licence, visit http://creativecommons.org/licenses/by/4.0/.

\section{References}

Adibi N, Ataee-pour M (2015) Decreasing minerals' revenue risk by diversification of mineral production in mineral rich countries. Resour Policy 45:121-129. https://doi.org/10. 1016/j.resourpol.2015.04.006

Agus M, Bortolussi A, Careddu N, Ciccu R, Grosso B, Massacci $\mathrm{G}$ (2003) Influence of stone properties on diamond wire performance. In: Fourth international conference on computer applications in the minerals industries (CAMI 2003), Guarapari, ES, Brazil

Ahmadi MA, Ebadi M, Shokrollahi A, Majidi SMJ (2013) Evolving artificial neural network and imperialist competitive algorithm for prediction oil flow rate of the reservoir. Appl Soft Comput 13(2):1085-1098

Akhyani M, Sereshki F, Mikaeil R, Taji M (2017) Evaluation of cutting performance of diamond saw machine using artificial bee colony (ABC) algorithm. Int J Min Geo-Eng 51(2): 185-190

Akhyani M, Sereshki F, Mikaeil R (2018) An investigation of the effect of toughness and brittleness indexes on ampere consumption and wear rate of a circular diamond saw. Rudarsko-geološko-naftni zbornik 33(4):85-93. https:// doi.org/10.17794/rgn.2018.4.8

Akhyani M, Mikaeil R, Sereshki F, Taji M (2019) Combining fuzzy RES with GA for predicting wear performance of circular diamond saw in hard rock cutting process. J Min Environ 10(3):559-574. https://doi.org/10.22044/jme. 2017.5770.1388

Almasi SN, Bagherpour R, Mikaeil R, Ozcelik Y, Kalhori H (2017a) Predicting the building stone cutting rate based on rock properties and device pullback amperage in quarries using M5P model tree. Geotech Geol Eng 35(4):1311-1326. https://doi.org/10.1007/s10706-0170177-0 
Almasi SN, Bagherpour R, Mikaeil R, Ozcelik Y (2017b) Analysis of bead wear in diamond wire sawing considering the rock properties and production rate. Bull Eng Geol Env 76(4):1593-1607. https://doi.org/10.1007/s10064-0171057-9

Almasi SN, Bagherpour R, Mikaeil R, Ozcelik Y (2017c) Developing a new rock classification based on the abrasiveness, hardness, and toughness of rocks and PA for the prediction of hard dimension stone sawability in quarrying. Geosyst Eng 20(6):295-310. https://doi.org/10.1080/ 12269328.2017.1278727

Ardalan Z, Karimi S, Poursabzi O, Naderi B (2015) A novel imperialist competitive algorithm for generalized traveling salesman problems. Appl Soft Comput 26:546-555. https://doi.org/10.1016/j.asoc.2014.08.033

Aryafar A, Mikaeil R (2016) Estimation of the ampere consumption of dimension stone sawing machine using of artificial neural networks. Int $\mathrm{J}$ Min Geo Eng 50(1):121-130

Aryafar A, Mikaeil R, Haghshenas SS, Haghshenas SS (2018a) Application of metaheuristic algorithms to optimal clustering of sawing machine vibration. Measurement 124:20-31. https://doi.org/10.1016/j.measurement.2018. 03.056

Aryafar A, Mikaeil R, Shafiee Haghshenas S (2018b) Utilization of soft computing for evaluating the performance of stone sawing machines, Iranian Quarries. Int J Min Geo Eng 52(1):31-36. https://doi.org/10.22059/IJMGE.2017. 233493.594673

Ataei M, Mikaiel R, Sereshki F, Ghaysari N (2011) Predicting the production rate of diamond wire saw using statistical analysis. Arab J Geosci 5(6):1289-1295. https://doi.org/ 10.1007/s12517-010-0278-z

Ataei M, Mikaeil R, Hoseinie SH, Hosseini SM (2012) Fuzzy analytical hierarchy process approach for ranking the sawability of carbonate rock. Int J Rock Mech Min Sci 50:83-93. https://doi.org/10.1016/j.ijrmms.2011.12.002

Atashpaz-Gargari E, Lucas C (2007) Imperialist competitive algorithm: an algorithm for optimization inspired by imperialistic competition. In: IEEE congress on evolutionary computation. IEEE, pp 4661-4667. https://doi.org/ 10.1109/CEC.2007.4425083

Birle JD, Ratterman E (1986) An approximate ranking of the sawability of hard building stones based on laboratory tests. Dimens Stone Mag 3(1):3-29

Burgess RB (1978) Circular sawing granite with diamond saw blades. In: Proceedings of the fifth industrial diamond seminar, pp 3-10

Buyuksagis IS (2007) Effect of cutting mode on the sawability of granites using segmented circular diamond sawblade. J Mater Process Technol 183(2-3):399-406. https://doi. org/10.1016/j.jmatprotec.2006.10.034

Buyuksagis IS, Goktan RM (2005) Investigation of marble machining performance using an instrumented block-cutter. J Mater Process Technol 169(2):258-262. https://doi. org/10.1016/j.jmatprotec.2005.03.014

Cai O, Careddu N (2013) The risk of irregular diamond wire beads wear. Diamante-Applicazioni \& Tecnologia, n. 75, Anno 19, Dicembre 2013, pagg. 33-41. Ed. G \& M Associated Sas. ISSN: 1824-5765
Careddu N, Cai O (2014) Granite sawing by diamond wire: from Madrigali "bicycle" to modern multi-wires. DiamanteApplicazioni \& Tecnologia, n. 79, Anno 20, 2014, 33-50. Ed. G \& M Associated Sas, Milano, Italy

Careddu N, Lanceni G (2015) The sawing of granite blocks with gang-saw: strong points of the traditional technology. Marmomacchine 243:12-25

Careddu N, Cai O, Perra ES (2018) Performance and issues of diamond wire in ornamental basalt quarries. Geoing Ambient Miner 155(3):85-92

Careddu N, Perra ES, Masala O (2019) Diamond wire sawing in ornamental basalt quarries: technical, economic and environmental considerations. Bull Eng Geol Environ 78:557-568. https://doi.org/10.1007/s10064-017-1112-6

Ciccu R, Agus M, Bortolussi A, Massacci G, Careddu N (1998) Diamond wire sawing of hard rocks. In: Proceedings of "superabrasive and CVD diamond-theory and application", Ultrahard Materials Technical Conference, May 28-30, 1998-Windsor, Ontario, Canada. Also printed in: Diamante-Applicazioni e Tecnologia, Dicembre 1998, pp 78-95, and in: Finer Points, 11(4): 22-30. Skyland, NC, Industrial Diamond Association of America (Pub)

Clausen R, Wang CY, Meding M (1996) Characteristics of acoustic emission during single diamond scratching of granite. Ind Diamond Rev 56(570):96-99

Dagrain F, Marchandise P, Brux P (2012) Monitoring of chain saw machines to follow their performances in quarries. Diam Appl Tecnol 69:43-49

Daneshvar D, Behnood A (2020) Estimation of the dynamic modulus of asphalt concretes using random forests algorithm. Int J Pavement Eng. https://doi.org/10.1080/ 10298436.2020.1741587

Delgado NS, Rodriguez R, Rio A, Sarria ID, Calleja L, Argandona VGR (2005) The influence of microhardness on the sawability of Pink Porrino granite (Spain). Int J Rock Mech Min Sci 42:161-166

Dormishi AR, Ataei M, Khaloo Kakaie R, Mikaeil R, Shaffiee Haghshenas S (2019a) Performance evaluation of gang saw using hybrid ANFIS-DE and hybrid ANFIS-PSO algorithms. J Min Environ 10(2):543-557. https://doi.org/10. 22044/JME.2018.6750.1496

Dormishi A, Ataei M, Mikaeil R, Khalokakaei R, Haghshenas SS (2019b) Evaluation of gang saws' performance in the carbonate rock cutting process using feasibility of intelligent approaches. Eng Sci Technol Int J 22(3):990-1000. https://doi.org/10.1016/j.jestch.2019.01.007

Dunda S, Kujundžić T (2001) Tensile strength of steel ropes of diamond wire saws. Rud.-geol.-naft. zb., vol 13, Zagreb.

Ebrahimi E, Mollazade K, Babaei S (2014) Toward an automatic wheat purity measuring device: a machine visionbased neural networks-assisted imperialist competitive algorithm approach. Measurement 55:196-205

Ersoy A, Atıc1 U (2004) Performance characteristics of circular diamond saws in cutting different types of rocks. Diam Relat Mater 13(1):22-37. https://doi.org/10.1016/j. diamond.2003.08.016

Ersoy A, Buyuksagic S, Atici U (2005) Wear characteristics of circular diamond saws in the cutting of different hard abrasive rocks. Wear 258(9):1422-1436. https://doi.org/ 10.1016/j.wear.2004.09.060 
Eyuboglu AS, Ozcelik Y, Kulaksiz S, Engin IC (2003) Statistical and microscopic investigation of disc segment wear related to sawing Ankara andesites. Int J Rock Mech Min Sci 40(3):405-414

Fener M, Kahraman S, Ozder MO (2007) Performance prediction of circular diamond saws from mechanical rock properties in cutting carbonate rocks. Rock Mech Rock Eng 40(5):505-517

Fiorini Morosini A, Haghshenas SS, Haghshenas SS, Geem ZW (2020) Development of a binary model for evaluating water distribution systems by a pressure driven analysis (PDA) approach. Appl Sci 10:3029. https://doi.org/10. 3390/app10093029

Geem ZW, Kim JH (2018) Application of computational intelligence techniques to an environmental flow formula. Int J Fuzzy Logic Intell Syst 18(4):237-244. https://doi. org/10.5391/IJFIS.2018.18.4.237

Ghaysari N, Ataei M, Sereshki F, Mikaiel R (2012) Prediction of performance of diamond wire saw with respect to texture characteristics of rock/Prognozowanie Wydajności Pracy Strunowej Piły Diamentowej W Odniesieniu do Charakterystyki Tekstury Skał. Arch Min Sci 57(4):887-900

Gnawali K, Han KH, Geem ZW, Jun KS, Yum KT (2019) Economic dispatch optimization of multi-water resources: a case study of an island in South Korea. Sustainability 11(21):5964. https://doi.org/10.3390/su11215964

Guido G, Haghshenas SS, Haghshenas SS, Vitale A, Astarita V, Haghshenas AS (2020a) Feasibility of stochastic models for evaluation of potential factors for safety: a case study in Southern Italy. Sustainability 12(18):7541. https://doi.org/ $10.3390 /$ su 12187541

Guido G, Haghshenas SS, Haghshenas SS, Vitale A, Gallelli V, Astarita V (2020b) Development of a binary classification model to assess safety in transportation systems using GMDH-type neural network algorithm. Sustainability 12(17):6735. https://doi.org/10.3390/su12176735

Gunaydin O, Kahraman S, Fener M (2004) Sawability prediction of carbonate rocks from brittleness indexes. J S Afr Inst Min Metall 104(4):239-243

Haghshenas SS, Haghshenas SS, Mikaeil R, Sirati Moghadam P, Haghshenas AS (2017) A new model for evaluating the geological risk based on geomechanical properties-case study: the second part of emamzade hashem tunnel. Electron J Geotech Eng 22(01):309-320

Haghshenas SS, Faradonbeh RS, Mikaeil R, Haghshenas SS, Taheri A, Saghatforoush A, Dormishi A (2019) A new conventional criterion for the performance evaluation of gang saw machines. Measurement 146:159-170. https:// doi.org/10.1016/j.measurement.2019.06.031

Hoseinie SH, Ataei M, Osanloo M (2009) A new classification system for evaluating rock penetrability. Int J Rock Mech Min Sci 46(8):1329-1340. https://doi.org/10.1016/j. ijrmms.2009.07.002

Hosseini SM, Ataei M, Khalokakaei R, Mikaeil R, Haghshenas SS (2019) Investigating the role of coolant and lubricant fluids on the performance of cutting disks (case study: hard rocks). Rudarsko-Geološko-Naftni Zbornik 34(2):13-24. https://doi.org/10.17794/rgn.2019.2.2

Hosseini SM, Ataei M, Khalokakaei R, Mikaeil R (2020a) An experimental investigation on the role of coolant and lubricant fluids in the maximum electrical current based upon the rock physical and mechanical properties. Geotech Geol Eng 38(2):2317-2326. https://doi.org/10.1007/ s10706-019-01101-x

Hosseini SM, Ataei M, Khalokakaei R, Mikaeil R, Haghshenas SS (2020b) Study of the effect of the cooling and lubricant fluid on the cutting performance of dimension stone through artificial intelligence models. Eng Sci Technol Int J 23(1):71-81. https://doi.org/10.1016/j.jestch.2019.04. 012

International Society for Rock Mechanics (1981) Rock characterisation, testing and monitoring: ISRM suggested methods. Pergamon, Oxford

Jennings M, Wright D (1989) Guidelines for sawing stone. Ind Diamond Rev 49(2):70-75

Kahraman S, Gunaydin O (2008) Indentation hardness test to estimate the sawability of carbonate rocks. Bull Eng Geol Env 67(4):507-511. https://doi.org/10.1007/s10064-0080162-1

Kahraman S, Fener M, Gunaydin O (2004) Predicting the sawability of carbonate rocks using multiple curvilinear regression analysis. Int $\mathrm{J}$ Rock Mech Min Sci 41(7):1123-1131. https://doi.org/10.1016/j.ijrmms.2004. 04.009

Kahraman S, Altun H, Tezekici BS, Fener M (2005) Sawability prediction of carbonate rocks from shear strength parameters using artificial neural networks. Int J Rock Mech Min Sci 43(1):157-164

Kahraman S, Ulker U, Delibalta MS (2007) A quality classification of building stones from P-wave velocity and its application to stone cutting with gang saws. J S Afr Inst Min Metall 107(7):427-430

Kamran MA, Khoshsirat M, Mikaeil R, Nikkhoo F (2017) Ranking the sawability of ornamental and building stones using different MCDM methods. J Eng Res 5(3)

Kandiri A, Golafshani EM, Behnood A (2020) Estimation of the compressive strength of concretes containing ground granulated blast furnace slag using hybridized multi-objective ANN and salp swarm algorithm. Constr Build Mater 248:118676. https://doi.org/10.1016/j.conbuildmat. 2020.118676

Kayabekir AE, Toklu YC, Bekdaş G, Nigdeli SM, Yücel M, Geem ZW (2020) A novel hybrid harmony search approach for the analysis of plane stress systems via total potential optimization. Appl Sci 10(7):2301. https://doi. org/10.3390/app10072301

Khabbazi A, Atashpaz-Gargari E, Lucas C (2009) Imperialist competitive algorithm for minimum bit error rate beamforming. Int J Bio-Inspired Comput 1(1-2):125-133

Mahdevari S, Shahriar K, Sharifzadeh M, Tannant DD (2017) Stability prediction of gate roadways in longwall mining using artificial neural networks. Neural Comput Appl 28(11):3537-3555. https://doi.org/10.1007/s00521-0162263-2

Maroufmashat A, Sayedin F, Khavas SS (2014) An imperialist competitive algorithm approach for multi-objective optimization of direct coupling photovoltaic-electrolyzer systems. Int J Hydrog Energy 39(33):18743-18757. https:// doi.org/10.1016/j.ijhydene.2014.08.125

Mikaeil R, Ozcelik Y, Ataei M, Yousefi R (2011) Correlation of specific ampere draw with rock brittleness indexes in rock sawing process. Arch Min Sci 56(4):777-788 
Mikaeil R, Ozcelik Y, Yousefi R, Ataei M, Hosseini SM (2013) Ranking the sawability of ornamental stone using Fuzzy Delphi and multi-criteria decision-making techniques. Int $\mathbf{J}$ Rock Mech Min Sci 58:118-126. https://doi.org/10.1016/j. ijrmms.2012.09.002

Mikaeil R, Abdolaahi KM, Sadegheslam G, Ataei M (2015) Ranking the sawability of dimension stone by using promethee. J Min Environ 6(2):263-271

Mikaeil R, Shaffiee Haghshenas S, Ozcelik Y, Shaffiee Haghshenas S (2017) Development of intelligent systems to predict diamond wire saw performance. Soft Comput Civ Eng 1(2):52-69. https://doi.org/10.22115/SCCE.2017. 49092

Mikaeil R, Haghshenas SS, Haghshenas SS, Ataei M (2018a) Performance prediction of circular saw machine using imperialist competitive algorithm and fuzzy clustering technique. Neural Comput Appl 29(6):283-292. https:// doi.org/10.1007/s00521-016-2557-4

Mikaeil R, Haghshenas SS, Ozcelik Y, Gharehgheshlagh HH (2018b) Performance evaluation of adaptive neuro-fuzzy inference system and group method of data handling-type neural network for estimating wear rate of diamond wire saw. Geotech Geol Eng 36(6):3779-3791. https://doi.org/ 10.1007/s10706-018-0571-2

Mikaeil R, Haghshenas SS, Hoseinie SH (2018c) Rock penetrability classification using artificial bee colony (ABC) algorithm and self-organizing map. Geotech Geol Eng 36(2):1309-1318. https://doi.org/10.1007/s10706-0170394-6

Mikaeil R, Ozcelik Y, Ataei M, Shaffiee Haghshenas S (2019a) Application of harmony search algorithm to evaluate performance of diamond wire saw. $J$ Min Environ 10(1):27-36. https://doi.org/10.22044/JME.2016.723

Mikaeil R, Bakhshinezhad H, Haghshenas SS, Ataei M (2019b) Stability analysis of tunnel support systems using numerical and intelligent simulations (case study: Kouhin Tunnel of Qazvin-Rasht Railway). Rudarsko-geološko-naftni zbornik 34(2):1-10. https://doi.org/10.17794/rgn.2019.2.1

Mikaeil R, Haghshenas SS, Sedaghati Z (2019c) Geotechnical risk evaluation of tunneling projects using optimization techniques (case study: the second part of Emamzade Hashem tunnel). Nat Hazards 97(3):1099-1113. https:// doi.org/10.1007/s11069-019-03688-z

Mikaeil R, Beigmohammadi M, Bakhtavar E, Haghshenas SS (2019d) Assessment of risks of tunneling project in Iran using artificial bee colony algorithm. SN Appl Sci 1(12):1711. https://doi.org/10.1007/s42452-019-1749-9

Mikaiel R, Ataei MA, Hoseinie H (2008) Predicting the production rate of diamond wire saws in carbonate rock cutting. IDR Ind Diam Rev 68(3):28-34

Mohammadi J, Ataei M, Kakaie R, Mikaeil R, Haghshenas SS (2019) Performance evaluation of chain saw machines for dimensional stones using feasibility of neural network models. J Min Environ 10(4):1105-1119. https://doi.org/ 10.22044/jme.2018.7013.1542

Mokhtarian Asl M, Sattarvand J (2016) An imperialist competitive algorithm for solving the production scheduling problem in open pit mine. Int $J$ Min Geo Eng 50(1):131-143. https://doi.org/10.22059/IJMGE.2016. 57862
Naderpour H, Nagai K, Haji M, Mirrashid M (2019) Adaptive neuro-fuzzy inference modelling and sensitivity analysis for capacity estimation of fiber reinforced polymerstrengthened circular reinforced concrete columns. Expert Syst 36(4):e12410. https://doi.org/10.1111/exsy.12410

Nazari-Shirkouhi S, Eivazy H, Ghodsi R, Rezaie K, AtashpazGargari E (2010) Solving the integrated product mix-outsourcing problem using the imperialist competitive algorithm. Expert Syst Appl 37(12):7615-7626. https://doi.org/ 10.1016/j.eswa.2010.04.081

Noori AM, Mikaeil R, Mokhtarian M, Haghshenas SS, Foroughi M (2020) Feasibility of intelligent models for prediction of utilization factor of TBM. Geotech Geol Eng 38:3125-3143. https://doi.org/10.1007/s10706-02001213-9

Ozcelik Y, Polat E, Bayram F, Ay AM (2004) Investigation of the effects of textural properties on marble cutting with diamond wire. Int J Rock Mech Min Sci 41:228-234

Özçelik Y (2007) The effect of marble textural characteristics on the sawing efficiency of diamond segmented frame saws. Ind Diamond Rev 2:65-70

Park JH, Yu JS, Geem ZW (2020) Optimal project planning for public rental housing in South Korea. Sustainability 12(2):600. https://doi.org/10.3390/su12020600

Polini W, Turchetta S (2007) Monitoring of diamond disk wear in stone cutting by means of force or acceleration sensors. Int J Adv Manuf Tech 35:454-467

Reichl C, Schatz M, Zsak G (2013) World-Mining-Data, International Organizing Committee for the World Mining Congresses, Volume/Heft 28 Vienna

Sadaei HJ, Enayatifar R, Lee MH, Mahmud M (2016) A hybrid model based on differential fuzzy logic relationships and imperialist competitive algorithm for stock market forecasting. Appl Soft Comput 40:132-149. https://doi.org/10. 1016/j.asoc.2015.11.026

Sadegheslam G, Mikaeil R, Rooki R, Ghadernejad S, Ataei M (2013) Predicting the production rate of diamond wire saws using multiple nonlinear regression analysis. Geosyst Eng 16(4):275-285. https://doi.org/10.1080/12269328.2013. 856276

Salemi A, Mikaeil R, Haghshenas SS (2018) Integration of finite difference method and genetic algorithm to seismic analysis of circular shallow tunnels (Case study: Tabriz urban railway tunnels). KSCE J Civ Eng 22(5):1978-1990. https://doi.org/10.1007/s12205-017-2039-y

Schimazek J, Knatz H (1970) Der Einfluß des Gesteinsaufbaus auf die Schnittgeschwindigkeit und den Meißelverschleiß von Streckenvortriebsmaschinen. Glückauf 106(6):274-278

Shaffiee Haghshenas S, Pirouz B, Shaffiee Haghshenas S, Pirouz B, Piro P, Na KS, Cho SE, Geem ZW (2020) Prioritizing and analyzing the role of climate and urban parameters in the confirmed cases of COVID-19 based on artificial intelligence applications. Int J Environ Res Public Health 17(10):3730

Sharifi MA, Mojallali H (2015) A modified imperialist competitive algorithm for digital IIR filter design. Optik Int J Light Electron Opt 126(21):2979-2984. https://doi.org/10. 1016/j.ijleo.2015.07.022

Shokrollahpour E, Zandieh M, Dorri B (2011) A novel imperialist competitive algorithm for bi-criteria scheduling of the 
assembly flowshop problem. Int J Prod Res 49(11):3087-3103. https://doi.org/10.1080/00207540903536155

Tumac D (2015) Predicting the performance of large diameter circular saws based on Schmidt hammer and other properties for some Turkish carbonate rocks. Int J Rock Mech Min Sci 75:159-168. https://doi.org/10.1016/j.ijrmms. 2015.01.015

Tumac D (2016) Artificial neural network application to predict the sawability performance of large diameter circular saws. Measurement 80:12-20. https://doi.org/10.1016/j. measurement.2015.11.025

Tumac D, Shaterpour-Mamaghani A (2018) Estimating the sawability of large diameter circular saws based on classification of natural stone types according to the geological origin. Int J Rock Mech Min Sci 101:18-32. https://doi.org/ 10.1016/j.ijrmms.2017.11.014

Tutmez B, Kahraman S, Gunaydin O (2007) Multifactorial fuzzy approach to the sawability classification of building stones. Constr Build Mater 21:1672-1679

Wei X, Wang CY, Zhou ZH (2003) Study on the fuzzy ranking of granite sawability. J Mater Process Technol 139(1-3): 277-280. https://doi.org/10.1016/S0924-0136(03)00235-8
Wright DN, Cassapi VB (1985) Factors influencing stone sawability. Ind Diamond Rev 45(2):84-87

Yang Y, Zhang Q (1997) A hierarchical analysis for rock engineering using artificial neural networks. Rock Mech Rock Eng 30(4):207-222. https://doi.org/10.1007/s00366019-00769-2

Yilmazkaya EMRE, Dagdelenler G, Ozcelik Y, Sonmez H (2018) Prediction of mono-wire cutting machine performance parameters using artificial neural network and regression models. Eng Geol 239:96-108. https://doi.org/ 10.1016/j.enggeo.2018.03.009

Yurdakul M, Akdas H (2012) Prediction of specific cutting energy for large diameter circular saws during natural stone cutting. Int J Rock Mech Min Sci 53:38-44. https://doi.org/ 10.1016/j.ijrmms.2012.03.008

Zhang T, Geem ZW (2019) Review of harmony search with respect to algorithm structure. Swarm Evol Comput 48:31-43. https://doi.org/10.1016/j.swevo.2019.03.012

Publisher's Note Springer Nature remains neutral with regard to jurisdictional claims in published maps and institutional affiliations. 